\title{
KONCEPCJA WSPÓECZESNEGO PRAWA OCHRONY ŚRODOWISKA A JEGO DYNAMICZNY ROZWÓJ
}

\section{THE CONCEPT OF MODERN ENVIRONMENTAL LAW AND ITS DYNAMIIC DEVELOPMENT}

\section{STRESZCZENIE}

Celem artykułu jest analiza współczesnej koncepcji prawa ochrony środowiska oraz analiza zachodzących w tej dyscyplinie prawniczej zmian, charakteryzujących się znaczną dynamiką. Przedmiotem badań jest zależność między koncepcją prawa ochrony środowiska a jego dynamicznym rozwojem, ze szczególnym uwzględnieniem wzajemnego oddziaływania między tymi dwoma elementami.

\section{Słowa kluczowe}

Prawo ochrony środowiska, zasada zrównoważonego rozwoju, prawo międzynarodowe, antropocentryzm

* Prof. dr hab., Kierownik Katedry Prawa Ochrony Środowiska UMK w Toruniu. 


\begin{abstract}
The purpose of this article is to analyze the modern concept of environmental law and dynamic changes which occur in this discipline of law. The concept of environmental law and its dynamic development are the main subject of this survey, with special regard to the interaction between those two elements.
\end{abstract}

\title{
Keywords
}

Environmental law, principle of sustainable development, international law, anthropocentrism

Prawo ochrony środowiska może być obecnie zaliczane do jednej z najbardziej dynamicznie rozwijających się dyscyplin prawniczych. Przyczyn dynamicznego rozwoju prawa ochrony środowiska jest kilka i można zaliczyć rozwijającą się świadomość legislatora, a także organów stosujących prawo, dynamiczny rozwój dyscyplin naukowych zajmujących się ochroną środowiska, a przede wszystkim ekologia i sozologia, coraz większa ingerencja człowieka w środowisko i wreszcie coraz poważniejsze skutki tej ingerencji dla współczesnego i przyszłych pokoleń. Jednocześnie dynamizm prawa ochrony środowiska rzutuje na jego koncepcję, która nie tylko, ulega zmianie, ale także musi zachowywać wystarczającą dla absorpcji tego dynamizmu elastyczność.

Artykuł ten jest analizą współczesnej koncepcji prawa ochrony środowiska oraz analizą zachodzących w tej dyscyplinie prawniczej zmian, które charakteryzują się znaczną dynamiką. Przedmiotem badań jest zależność między koncepcją prawa ochrony środowiska, a jego dynamicznym rozwojem, ze szczególnym uwzględnieniem wzajemnego wpływu tych dwóch elementów.

Historia prawa ochrony środowiska jest stosunkowo krótka, choć w piśmiennictwie wskazuje się na jego korzenie nie tylko $\mathrm{w}$ prawie okresu średniowiecza, ale nawet $\mathrm{w}$ prawie antycznym ${ }^{1}$. Jednak o nowoczesnym prawie ochrony środowiska,

1 Rozważania o rzymskim prawie ochrony środowiska prowadził C. Kunderewicz, który opublikował wyniki swoich badań w opracowaniach Ochrona 
uwzględniającym nie tylko zagadnienia partykularne ale również prawo międzynarodowe, można mówić dopiero od przełomu lat 60 i 70 ubiegłego wieku.

Za początek rozwoju współczesnego prawa ochrony środowiska można uznać Konferencję ONZ i sporządzony przez jej ówczesnego Sekretarza Generalnego raport „Człowiek i środowisko"2. Szczegółowa analiza, przeprowadzona w tym raporcie obejmowała wpływ człowieka na stan środowiska, a także ocenę tego stanu. Jednocześnie wnioski, wynikające $\mathrm{z}$ tej analizy zdeterminowały koncepcję prawnej ochrony środowiska.

U podstaw tej koncepcji legło kilka podstawowych założeń aksjologicznych. Po pierwsze instrumenty prawne miały przede wszystkim pełnić rolę protekcyjną w stosunku do środowiska. $\mathrm{W}$ normie prawnej upatrywano przede wszystkim elementu ochronnego. Stąd też wywodzi się dominująca w prawie ochrony środowiska metoda regulacji, jaką jest metoda administracyjna, a w ślad za nią wprowadzenie do prawa ochrony środowiska metod działania, charakterystycznych dla administracji publicznej. Prawo ochrony środowiska charakteryzowało się zatem szerokim zakresem wykorzystywania metody władczej z silną pozycją organu administracji publicznej.

Po drugie, pomimo prób globalnego spojrzenia na problematykę ochrony środowiska, nadal dominowała metoda, polegająca na partykularnym uregulowaniu ochrony poszczególnych elementów środowiska, zamiast na podejmowaniu prób całościowego i kompleksowego spojrzenia na zagadnienia powiązane ze środowiskiem i jego stanem. Stąd też wywodzi się tradycyjny sposób regulacji poszczególnych elementów środowiska w odrębnych aktach prawnych.

Po trzecie dostrzeżono konieczność większego wykorzystania instrumentów prawa międzynarodowego publicznego i zwiększenie roli społeczności międzynarodowej dla ochrony środowiska w wymiarze globalnym ${ }^{3}$.

środowiska naturalnego $w$ prawie rzymskim, Czasopismo Prawno - Historyczne z 1981, nr 2 s. 1-10; Studia z rzymskiego prawa administracyjnego, Łódź 1991.

2 Tak przyjmuje m.in. R. Paczuski, Ochrona środowiska. Zarys wykładu, Bydgoszcz 2008, s. 17.

3 Zob. bliżej M. M. Kenig-Witkowska, Międzynarodowe prawo środowiska. Wybrane zagadnienia systemowe, Warszawa 2011. 
Po czwarte istotnym elementem koncepcji prawa ochrony środowiska były jego elementy antropocentryczne. Doszło bowiem do nowego ujęcia sytuacji prawnej jednostki ze względu na środowisko. Dostrzeżono związek pomiędzy stanem środowiska, a jakością zdrowia, a nawet życia człowieka. Normy prawne, które w zasadzie pełniły rolę ochronną wobec środowiska, równocześnie służyły ochronie życia i zdrowia człowieka.

J. Boć i E. Samborska-Boć wśród przesłanek ochrony środowiska wymienili przesłanki biologiczne, społeczne i ekonomiczne ${ }^{4}$, co odpowiada podstawowym założeniom koncepcyjnym prawa ochrony środowiska.

Wytyczone na przełomie lat 60 i 70 aksjologiczne podstawy prawa ochrony środowiska i w konsekwencji kierunki jego rozwoju, ulegały, na przestrzeni minionych pięćdziesięciu lat znacznej przebudowie, co doprowadziło do powstania współczesnej koncepcji prawa ochrony środowiska. Przyczyn przebudowy koncepcji można upatrywać w kilku istotnych elementach. Po pierwsze istotne znaczenie odgrywa ciągły rozwój technologiczny, a także stan badań nad środowiskiem, jego zagrożeniami i sposobami radzenia sobie $z$ tymi zagrożeniami.

Po drugie istotne znaczenie mają pojawiające się nowe wyzwania dla legislatora, które są wynikiem konieczności jego reakcji na pojawiające się co rusz nowe zagrożenia dla środowiska np. klonowanie, GMO, efekt cieplarniany itp.

Po trzecie, za istotną przyczynę zmian w prawie ochrony środowiska należy również uznać wzrost samoświadomości jednostki i będące konsekwencją tego wzrostu dążenie do zwiększenia działań ochronnych.

Wywołane tymi przyczynami zmiany w prawie ochrony środowiska, doprowadziły do wypracowania współczesnej koncepcji regulacji prawnych. Obecnie w prawie ochrony środowiska nie można już jedynie upatrywać elementów ochronnych. Współczesne prawo ochrony środowiska nie zajmuje się już zagadnieniem, czy oddziaływać na środowisko i jego zasoby, co było charakterystyczne dla początków prawa ochrony środowi-

4 J. Boć, E. Samborska-Boć, [w:] J. Boć, E. Samborska-Boć, K. Nowacki, Ochrona środowiska, Kolonia 2008, s. 57- 64. 
ska, ale zajmuje się tym, jak na środowisko oddziaływać. Nastąpiło zatem przesunięcie akcentu z funkcji ochronnej prawa ochrony środowiska na funkcję dystrybucyjną.

Współczesna koncepcja prawa ochrony środowiska koncentruje się wokół dystrybucji dostępu do środowiska i jego zasobów $^{5}$. W konsekwencji rola organu administracji publicznej przesunęła się z funkcji ochronnej na funkcję dystrybucyjną. Rola organu administracji publicznej sprowadza się zatem przede wszystkim do określania kto, kiedy i na jakich warunkach może ze środowiska korzystać. Oczywiście zakres tego korzystania wyznacza przede wszystkim ustawa.

Punktem zwrotnym dla zmiany koncepcji prawa ochrony środowiska z ochronnej na dystrybucyjną była Konferencja w Rio de Janeiro w 1992 roku, na której wypracowano kompleksową, a zarazem spójną koncepcję zrównoważonego rozwoju ${ }^{6}$. Istotą koncepcji zrównoważonego rozwoju jest przede wszystkim wyważenie różnych wartości prawem chronionych, które pozostają ze sobą w naturalnym konflikcie, przy czym jedną z tych wartości jest środowisko i jego ochrona.

Owo rozwiązywanie konfliktów, czy też inaczej rzecz ujmując wyważanie sprzecznych interesów, wiąże się przede wszystkim z tym, że należy eliminować antagonizmy pomiędzy różnymi wartościami prawem chronionymi ${ }^{7}$. Koncepcja zrównoważonego rozwoju sprowadza się do jak najszerszego i najczęstszego a także najpełniejszego urzeczywistniania różnych wartości prawem chronionych. Rolą organu stanowiącego prawo, a także organu je stosującego jest godzenie ze sobą sprzecznych wartości, a nie ich konfrontowanie. Stąd też nastąpiło przemodelowanie koncepcji prawa ochrony środowiska właśnie w kie-

5 Por. B. Rakoczy, Konstytucyjna zasada sprawiedliwości społecznej, a ochrona środowiska $w$ działalności przedsiębiorcy, [w:] J. Ciechanowicz-McLean (red.), T. Bojar-Fijałkowski (red.), Prawo ochrony środowiska jako warunek prowadzenia działalności gospodarczej, Gdańsk 2009, s. 89-98.

6 Zasada ta była przedmiotem analizy m.in. w monografii Z. Bukowskiego, Zrównoważony rozwój w systemie prawa, Toruń 2009.

7 J. Ciechanowicz-McLean zwraca uwagę na owe konflikty, wskazując jednocześnie jakie znaczenie ma tzw. ekoterroryzm, Prawo i polityka ochrony środowiska, Warszawa 2009, s. 64 i n. 
runku dystrybucyjnym, z redukcją znaczenia funkcji ochronnej prawa ochrony środowiska.

Współczesne prawo ochrony środowiska przede wszystkim koncentruje się na tym, komu na jakich warunkach i w jakim zakresie umożliwić dostęp do środowiska i możliwość korzystania z niego. Natomiast zmniejszeniu uległa rola organu, jako podmiotu uwzględniającego przede wszystkim ochronny charakter prawa ochrony środowiska.

Konsekwencją wiodącej roli funkcji ochronnej było to, że zwiększał się konfrontacyjny charakter prawa ochrony środowiska wobec innych obszarów regulacji prawnej, w którym za wiodący element należy uznać ochronę praw i wolności jednostki. Prawo ochrony środowiska mogło być postrzegane jako ten obszar regulacji prawnych, który na jednostkę nakładał zbytnie obciążenia, a przede wszystkim ograniczał jej uprawnienia ${ }^{8}$.

Wzmocnienie funkcji dystrybucyjnej prawa ochrony środowiska, przy jednoczesnym zmniejszeniu roli funkcji ochronnej, spowodowało, iż zarówno organy stanowiące prawo jak i je stosujące, zobowiązane są uwzględniać nie tylko interes środowiska, jako dobra wspólnego, ale również interes prywatny jednostki, której uprawnienia mogą ulec uszczupleniu, ze względu na konieczność ochrony środowiska.

W związku z zasadą zrównoważonego rozwoju za podstawowy sposób stanowienia prawa i jego stosowania należy uznać taki, który pozwoli w jak najlepszy sposób urzeczywistnić różne wartości prawem chronione, pozostające ze sobą w konflikcie. Dopiero w wyjątkowej sytuacji wolno organowi stanowiącemu prawo a także je stosującemu rozstrzygnąć konflikt, na korzyść jednej z tych wartości. Oczywiście wymaga to właściwego uzasadnienia, dlaczego taki wybór został dokonany. Jednak, co istotne, ów element konfrontacyjny ma charakter wyjątku od zasady.

Istotnym elementem współczesnego prawa ochrony środowiska jest również to, że zmierza ono do ochrony środowiska jako jednej całości, a nie do ochrony jego poszczególnych ele-

8 B. Rakoczy, Ograniczenie praw i wolności jednostki ze względu na ochronę środowiska w Konstytucji Rzeczypospolitej Polskiej, Toruń 2006. 
mentów. J. Sommer analizując pojęcie koncepcji zintegrowanej ochrony środowiska i zauważając wieloznaczność tego pojęcia, wskazał też, że „[...] ochrona środowiska wymaga, aby oddziaływania na środowisko nie były rozpatrywane jako obciążenia oddziellnych mediów środowiskowych, ale jako oddziaływanie na środowisko jako całość i w tym charakterze zwalczane lub ograniczane" " Za wartość prawem chronioną uznać można zatem nie tylko poszczególne elementy środowiska, ale także wzajemne oddziaływanie między nimi. Stąd też we współczesnym prawie ochrony środowiska dominują elementy integrystyczne, natomiast elementy separacyjne traca obecnie na znaczeniu. Dominacja elementów integrystycznych nad elementami separatystycznymi nie oznacza jednak, iż poszczególne elementy środowiska nie powinny być traktowane odmiennie $\mathrm{z}$ uwzględnieniem ich specyfiki.

Nie ma bowiem możliwości całkowicie jednolitego potraktowania wszystkich elementów środowiska i poddania ich jednolitej i takiej samej regulacji, gdyż doprowadziłoby to do niewłaściwych i niepożądanych skutków. Już bowiem z samej natury poszczególnych elementów przyrodniczych wynika konieczność ich odrębnego traktowania.

Właściwe jest zatem integrystyczne podejście do ochrony środowiska jako zasada przy jednoczesnym traktowaniu elementów separatystycznych, jako wyjątku, z tym jednak zastrzeżeniem, że uwzględnianie specyfiki poszczególnych elementów przyrodniczych jest wskazane i uzasadnione.

Można wreszcie zauważyć, iż współczesne prawo ochrony środowiska i jego przyszłość mogą być zdeterminowane zwiększającą się rolą elementów separatystycznych, z tym, że separacja ta następuje według innych kryteriów niż tradycyjnie ujmowane podziały na poszczególne elementy środowiska. Przykładem takich tendencji jest zwiększający się zakres ochrony klimatu, jako wartości prawem chronionej ${ }^{10}$. Coraz częściej

9 J. Sommer, [w:] W. Radecki (red.), Podstawy teoretyczne zintegrowanej ochrony prawnej środowiska, Wrocław 2010, s. 14

10 Zob. B. Rakoczy, The role of the laws in the protection of the climat, Climate Change, Global Risk, Challenges \& Decisions. Abstract books, Copen- 
można zauważyć, iż ochrona klimatu wyodrębniana jest z ochrony środowiska, a klimat jest traktowany jako wartość prawem chroniona samodzielnie, niezależnie od ochrony środowiska.

Kolejną istotną cechą prawa ochrony środowiska jest zwiększająca się rola płaszczyzn regulacji normatywnej, ponadnarodowej. Przyczyną zwiększania się roli regulacji ponadnarodowych jest to, że dostrzeżono, iż zagadnienia związane ze środowiskiem $i$ jego ochroną nie mogą być jednie regulowane w systemie prawa krajowego z uwagi na to, że środowisko jako przedmiot regulacji normatywnej przekracza granice państw, a w konsekwencji i systemu prawa krajowego. Koncepcja współczesnego prawa ochrony środowiska idzie jeszcze dalej i przyjmuje, że ochrona niektórych elementów środowiska możliwa jest właściwie jedynie na płaszczyźnie prawno międzynarodowej, a przynajmniej na tej płaszczyźnie powinny być przyjęte podstawowe instrumenty ochrony prawnej środowiska.

Jednak zwiększająca się rola ponadnarodowego sposobu regulowania problematyki ochrony środowiska, nie jest pozbawiona pewnych mankamentów. Podstawowym mankamentem jest to, że źródłem prawa międzynarodowego publicznego, w tym również międzynarodowego prawa środowiska jest umowa. Zakłada ona dobrowolność państw - stron zawarcia takiej umowy.

Prawo międzynarodowe publiczne nie dysponuje instrumentami przymuszającymi państwo do zawarcia takiej umowy, a zatem jego skuteczność ma charakter warunkowy. Wprawdzie europejskie prawo środowiska, koncentrujące się współcześnie w aktach rangi dyrektywy, zna instrumenty przymuszenia państwa członkowskiego do przestrzegania norm prawnych, mających za przedmiot ochrony środowisko. Niemniej jednak skuteczność europejskiego prawa środowiska ograniczona jest jedynie do obszaru Europy i to też tylko w odniesieniu do niektórych jej państw.

hagen 2009 IOP Conf. Series: Earth and Environmental Science z 2009, z. 6, 112036; Climate protection in Polish legal system, Polish Yearbook of Environmental Law 2011, Toruń 2011, s. 101-111. 
Za ważną cechę współczesnego prawa ochrony środowiska należy również uznać zachwianie koncepcji antropocentrycznego charakteru tej dyscypliny prawniczej. Tendencje współczesnego prawa ochrony środowiska zmierzają raczej do tego, aby upodmiotowić środowisko, a przynajmniej niektóre z jego elementów.

Wzmocnienie nurtu zmierzającego do upodmiotowienia środowiska, lub jego elementów powoduje jednocześnie osłabienie nurtu antropocentrycznego. Zauważyć można zarysowujący się konflikt pomiędzy środowiskiem, a człowiekiem. Człowiek traktowany jest nie tyle $\mathrm{w}$ kategoriach podmiotu ochrony prawnej, ile w kategoriach największego zagrożenia dla środowiska. Jednocześnie zauważyć można zanikanie koncepcji uznających, iż ochrona środowiska ma przede wszystkim służyć jakości życia i zdrowia człowieka.

Da się zaobserwować, iż ochrona środowiska nie jest wykonywana dla dobra człowieka, jako podmiotu prawa, ale wykonywana jest dla środowiska, dla samego środowiska. Za ostateczną wartość wymagającą ochrony prawnej nie uznaje się człowieka, któremu należy zapewnić środowisko właściwej jakości, a także możliwość korzystania ze środowiska, ale uznaje się środowisko. Konsekwencją takiego ujęcia podstaw aksjologicznych jest to, że środowisko jest chronione jako wartość samoistna, także przed samym człowiekiem. Z kolei konsekwencją uznania środowiska za dobro samoistne jest jego antropomorfizacja przy czym, dotyczy to nie tylko środowiska jako takiego, ale także jego poszczególnych elementów ${ }^{11}$.

Oczywiście natężenie upodmiotowienia poszczególnych elementów środowiska jest różne. Przy czym występuje ono w największym zakresie w odniesieniu do zwierząt. W piśmiennictwie dopuszcza się nawet uznawanie praw zwierząt, miejsce prawnej ochrony zwierząt. Uznanie, że zwierzę ma prawo, wywołuje ten skutek, że owo zwierzę powinno być traktowane jako podmiot prawa. Jednak współczesne prawo ochrony śro-

11 B. Rakoczy, Moralność prawa ochrony środowiska, [w:] A. Madeja (red.), Nam hoc natura aequum est... Księga Jubileuszowa ku czci Profesora Janusza Justyńskiego $w$ siedemdziesięciolecie urodzin, Toruń 2012, s. 533-545 
dowiska nie opowiedziało się jeszcze jednoznacznie za tym, czy podstawową wartością prawem chronioną jest człowiek, a środowisko podlega ochronie ze względu na człowieka, czy też środowisko jest samodzielną wartością, niezależnie od ochrony przysługującej człowiekowi jako podmiotowi prawa. Natomiast tendencje, które da się zaobserwować w prawie ochrony środowiska zmierzają do tego, aby urzeczywistnić tą drugą koncepcję, według której środowisko jest samodzielną wartością prawem chronioną.

Już tylko sama analiza koncepcji współczesnego prawa ochrony środowiska pokazuje, dynamizm tej dyscypliny prawniczej. Dynamizm ten jest z jednej strony pozytywnym elementem prawa ochrony środowiska, zaś z drugiej strony niesie za sobą również i negatywne skutki. W konsekwencji legislator staje przed nie małym dylematem, gdyż z jednej strony powinien umieć reagować na dynamizm prawa ochrony środowiska, a z drugiej strony powinien ten dynamizm redukować do minimum.

Zauważyć również należy, że ów dynamiczny rozwój prawa ochrony środowiska $\mathrm{z}$ jednej strony jest na prawodawcy wymuszany szybko zmieniającą się rzeczywistością, a z drugiej strony sam jest przez tego ustawodawcę kreowany.

Punktem wyjścia do dalszych rozważań, dotyczących dynamizmu prawa ochrony środowiska, powinno być stwierdzenie, że ów dynamizm ma charakter wtórny wobec zmieniającej się rzeczywistości. Inaczej rzecz ujmując można wskazać, że zakres i szybkość zmian rzeczywistości i wpływ tych zmian na środowisko, wymusza na prawodawcy umiejętność szybkiego i właściwego reagowania. A. Lipiński dostrzegając ową cechę prawa ochrony środowiska łączy ją z członkostwem Polski w Unii Europejskiej. Stwierdza On, iż „Niezbędną przesłanką tego ostatniego [tj. członkostwa Polski w UE - przyp. B. R.] było bowiem wdrożenie unijnych wymagań środowiskowych . Mają one charakter otwarty i ulegają nieustannym przemianom. [...] $\mathrm{W}$ konsekwencji system prawa ochrony środowiska $\mathrm{W}$ Polsce ulega nieustannym przemianom"12.

12 A. Lipiński, Prawne podstawy ochrony środowiska, wyd. 5, Warszawa 2010, s. 13. 
Podstawową funkcją jaką pełni prawo w ochronie środowiska jest funkcja prewencyjna ${ }^{13}$. Prawodawca powinien zatem w pierwszej kolejności przyjmować takie rozwiązania prawne, które zapobiegną niepożądanemu oddziaływaniu na środowisko. To z kolei wymusza na legislatorze, aby być krok przed pojawiającymi się zagrożeniami, lub zagrożeniami które się mogą pojawić. Przykładem takich elementów w prawie ochrony środowiska jest zasada prewencji i zasada przezorności.

Przyczyny dynamizmu prawa ochrony środowiska, jak juz wyżej wskazano, nie są wywołane jedynie szybko zmieniającą się rzeczywistością ale również spowodowane są działalnością samego prawodawcy. Dobrym przykładem na negatywne aspekty dynamizmu prawa ochrony środowiska jest ustawa $\mathrm{z}$ dnia 27 kwietnia 2001 r. Prawo ochrony środowiska, która w okresie 12 lat obowiązywania była już nowelizowana kilkadziesiąt razy. Obecnie zaobserwować można niepokojący wzrost dynamizmu w przepisach dotyczących gospodarki odpadami, a także w prawie wodnym.

Przyczyn negatywnego dynamizmu jest kilka. Za podstawową przyczynę należy uznać niedomagania legislacyjne, które dotykają nie tylko prawa ochrony środowiska, ale również inne gałęzie i działy prawa. Inną przyczyną negatywnego dynamizmu w prawie ochrony środowiska jest poziom legislacji. Podstawowym sposobem zapobiegania negatywnemu dynamizmowi jest stworzenie spójnej, jasnej i odpornej na zmiany aksjologicznej koncepcji prawa ochrony środowiska. Być może sposobem na osiągniecie takiego celu byłaby konieczność kodyfikacji prawa ochrony środowiska.

Legislator powinien również zrezygnować z traktowania norm prawa ochrony środowiska jak instrukcji, i starać się zbliżyć bardziej do generalnego i abstrakcyjnego charakteru norm prawnych, niż do kazuistycznego i szczegółowego regulowania materii $^{14}$.

13 Por. P. Korzeniowski, Zasady prawne ochrony środowiska, Łódź 2010.

14 Szczyt kazuistyki został chyba osiągnięty w ustawie o utrzymaniu czystości i porządku w gminach, na co uwagę zwraca W. Radecki, Ustawa 
Kolejną przyczyną negatywnego dynamizmu prawa ochrony środowiska jest także to, że nie zakończył się jeszcze proces kształtowania struktur organów administracji publicznej, odpowiedzialnych za ochronę środowiska. Okres ostatnich kilkunastu lat obejmuje liczne i nierzadko nieprzemyślane zmiany organów administracji publicznej, kompetentnych w określonych sprawach.

Ów dynamizm negatywny, który nie jest spowodowany umiejętnością prawodawcy reagowania na zmieniające się potrzeby $\mathrm{w}$ zakresie ochrony środowiska, wymaga poszukiwania pewnych elementów, stabilizujących cały system prawnej ochrony środowiska. Obecnie jedynych elementów stabilizujących polskie prawo ochrony środowiska upatrywać można w kompleksowej regulacji konstytucyjnych podstaw ochrony środowiska.

Reasumując należy stwierdzić, że współczesne prawo ochrony środowiska charakteryzuje się kilkoma cechami. Przede wszystkim regulacje mają charakter kompleksowy i dotyczą bardziej środowiska jako całości, niż jego poszczególnych elementów. Po drugie dostrzec można również wzrastającą rolę uregulowań prawno międzynarodowych zarówno o charakterze ogólnoświatowym, jak i o charakterze regionalnym.

Po trzecie przebudowie ulega również centralna wartość, wokół której koncentruje się prawo ochrony środowiska. O ile w jego początkowej fazie w grę wchodziła ochrona środowiska ze względu na ochronę życia lub zdrowia człowieka, o tyle obecnie $\mathrm{w}$ prawie ochrony środowiska dostrzec można upodmiotowienie samego środowiska i traktowanie go jak wartości samej w sobie.

W prawie ochrony środowiska dostrzec również można, jako jego istotną cechę umiejętność właściwego i szybkiego reagowania legislatora na zmieniające się uwarunkowania środowiskowe. Tak pojmowany dynamizm prawa ochrony środowiska powinien być uznany za jego istotną cechę i wartość. Ów dynamizm może być osiągnięty poprzez tworzenie elastycznych 
regulacji prawnych. Istnieje jednak również dynamizm negatywny, którego źródłem jest ogólnie rzecz ujmując, niewłaściwe podejście legislatora do procesu stanowienia prawa. $\mathrm{W}$ tym wypadku działania legislatora godzą w stabilność przyjętych rozwiązań prawnych, a tym samym winny być eliminowane.

Kontakt e-mail:

kpos@umk.pl 